\title{
Mitotic Spindle Assembly Checkpoint Protein MAD2A
}

National Cancer Institute

\section{Source}

National Cancer Institute. Mitotic Spindle Assembly Checkpoint Protein MAD2A. NCI

Thesaurus. Code C105849.

Mitotic spindle assembly checkpoint protein MAD2A (205 aa, $24 \mathrm{kDa}$ ) is encoded by the human MAD2L1 gene. This protein is involved in the mitotic spindle-assembly checkpoint. 